\title{
ムライトーガラス系基板材料の検討
}

\author{
牛房信之・坂元耕三・永山更成・荻原覚 \\ （(株）日立製作所日立研究所，317 日立市幸町 3-1-1)

\section{Study of Mullite-Glass Ceramics for Substrates}

\author{
Nobuyuki USHIFUSA, Koozoo SAKAMOTO, Koosei NAGAYAMA and Satoru OGIHARA \\ (Hitachi Research Laboratory, Hitachi, Ltd., 3-1-1, Saiwai-cho, Hitachi-shi, Ibaraki \\ 317)
}

\begin{abstract}
Mullite $\left(3 \mathrm{Al}_{2} \mathrm{O}_{3} \cdot 2 \mathrm{SiO}_{2}\right)$ has a low thermal expansion coefficient and low dielectric constant, so it is a favorable material for substrate applications. It is difficult, however, to sinter pure mullite ceramics even above $1700^{\circ} \mathrm{C}$. Thus, mullite ceramics containing glass additives $\left(\mathrm{Al}_{2} \mathrm{O}_{3}-\mathrm{MgO}-\mathrm{SiO}_{2}\right.$ glass) which could be sintered at about $1600^{\circ} \mathrm{C}$ were fabricated and their properties were investigated. At about 90 wt\% of silica content in glass, the mullite ceramics has a low dielectric constant (5.9), high bending strength $(210 \mathrm{MPa})$ and low thermal expansion coefficient $\left(3.5 \times 10^{-6} /{ }^{\circ} \mathrm{C}\right)$. From electron diffraction analysis, sillimanite $\left(\mathrm{Al}_{2} \mathrm{O}_{3} \cdot \mathrm{SiO}_{2}\right)$ crystals were observed at boundaries of these ceramics. These ceramics showed little grain growth, responsible for their high bending strength. Substrate of mullite ceramics are suitable for mounting silicon devices.

[Received September 25, 1989 ; Accepted December 11, 1989]
\end{abstract}

Key-words: Mullite, Glass, Ceramics, Substrate, Dielectric constant, Bending strength, Thermal expansion coefficient, Microstructure

\section{1. 緒 言}

ムライト $\left(3 \mathrm{Al}_{2} \mathrm{O}_{3} \cdot 2 \mathrm{SiO}_{2}\right)$ は, $\mathrm{Al}_{2} \mathrm{O}_{3}-\mathrm{SiO}_{2} 2$ 成分系 において常圧下で安定に存在する唯一の化合物であ る11. ムライトは, アルミナに比べ熱膨張係数が小さく, 誘電率が小さいため，シリコンのウェハやチップを直接 搭載する基板として広い応用が期待できる。しかし，ム ライトは，元来焼結性が悪いことを利用して，耐火物と して多く使用されている化合物である。ムライト単独で は，約 $1600^{\circ} \mathrm{C}$ の温度でも十分に焼結が進まない。この ため，アルミナと同様に，最適な添加剤の開発が望まれ ている ${ }^{21 ~ 4)}$. 更に, ムライトの熱膨張係数 $\left(5.0 \times 10^{-6} /{ }^{\circ} \mathrm{C}\right)$ は, シリコンのそれ $\left(3.5 \times 10^{-6} /{ }^{\circ} \mathrm{C}\right)$ に比べやや大きい ため, シリコンチップの接続部の高い信頼性を確保する ためには，その值をシリコンに近付ける必要がある。ま た，基板としては，電気信号入出力用ピン，LSI チッ プ等の接続が必要であり，これらの接続信頼性を確保す るために，実装に耐えうる材料強度が要求される。これ と同時に誘電率を更に下げることにより，電気信号伝播 の高速化も望まれる．ムライト材料の誘電率を小さくす るためには，ムライト単独 $\left(\varepsilon_{\mathrm{r}}: 7.5\right)$ より比誘電率の 小さい材料を複合することが有効である。シリカは，無 機酸化物中最も誘電率が小さい材料であり，ムライトへ の添加剤として，このシリカを多く含むガラスを使用す
ることにより，ムライト材料の低誘電率化が可能と考え られる。これらの理由から，ムライトに焼結助剤として ガラスを添加する方法により，比較的低温で焼結可能な 低熱膨張, 高強度, 低誘電率材料の開発を試みた。 ガラ スとしては, 化学的に定安な $\mathrm{MgO}-\mathrm{Al}_{2} \mathrm{O}_{3}-\mathrm{SiO}_{2} 3$ 成分 系の材料を用いた.この $\mathrm{MgO}-\mathrm{Al}_{2} \mathrm{O}_{3}-\mathrm{SiO}_{2} 3$ 成分系に おいて, 最低の液相温度はトリジマイト $\left(\mathrm{SiO}_{2}\right)$-プロ トエンスタタイト $\left(\mathrm{MgO} \cdot \mathrm{SiO}_{2}\right)$-コーディエライト (2 $\mathrm{MgO} \cdot 2 \mathrm{Al}_{2} \mathrm{O}_{3} \cdot 5 \mathrm{SiO}_{2}$ ) の共融点 $1345^{\circ} \mathrm{C}$ で、コーディ エライトーエンスタタイト $\left(\mathrm{MgO} \cdot \mathrm{SiO}_{2}\right)$-フォルステラ イト $\left(2 \mathrm{MgO} \cdot \mathrm{SiO}_{2}\right)$ の共融点 $1360^{\circ} \mathrm{C}$ も同程度の温度 である ${ }^{51.6)}$. また, $\mathrm{SiO}_{2}$ が比較的多い組成領域 $(45$ - 75 $\mathrm{wt} \%)$ 内には, $1500^{\circ} \mathrm{C}$ 以下で融液を作る組成が存在する. 中でもコーディエライトは, 熱膨張係数が小さく, 比誘 電率が小さい $\left(\varepsilon_{\mathrm{r}}: 5.0\right)$ ことが知られており，ムライ 卜の焼結助剤として有望と考えられる.

\section{2. 実験方法}

\section{1 使用した原料}

表 1 に実験に使用した原料をまとめて示す。

2.2 原料粉末の配合組成

原料粉末の配合組成を表 2 に示す。ムライトの焼結助 剂としては, $\mathrm{Al}_{2} \mathrm{O}_{3}-\mathrm{MgO}-\mathrm{SiO}_{2} 3$ 成分系において, 比較 
Table 1. Raw materials.

\begin{tabular}{|c|c|c|}
\hline powder & material & particle size \\
\hline Mullite & $3 \mathrm{Al}_{2} \mathrm{O}_{3} \cdot 2 \mathrm{SiO}_{2}$ & $2.7 \mu \mathrm{m}$ \\
\hline Alumina & $\mathrm{Al}_{2} \mathrm{O}_{3}$ & $0.3 \mu \mathrm{m}$ \\
\hline$\alpha$-Quartz & $\mathrm{SiO}_{2}$ & $1.0 \mu \mathrm{m}$ \\
\hline Hydromagnesite & $\mathrm{Mg}_{5}\left(\mathrm{CO}_{3}\right)_{4}(\mathrm{OH})_{2} \cdot 4 \mathrm{H}_{2} \mathrm{O}$ & $1.0 \mu \mathrm{m}$ \\
\hline
\end{tabular}

Table 2. Composition of samples.

\begin{tabular}{|c|c|c|c|c|}
\hline No. & $\begin{array}{c}\text { Mullite } \\
3 \mathrm{Al}_{2} \mathrm{O}_{3} \cdot 2 \mathrm{SiO}_{2}\end{array}$ & $\begin{array}{c}\text { Alumina } \\
\mathrm{Al}_{2} \mathrm{O}_{3}\end{array}$ & $\begin{array}{c}\alpha \text {-Quartz } \\
\mathrm{Si}_{2}\end{array}$ & $\begin{array}{c}\text { Magnesia (Hydromagnesite] } \\
\left.\mathrm{MgO}^{2} \mathrm{Mg}_{5}\left(\mathrm{CO}_{3}\right)_{4}(\mathrm{OH})_{2} \cdot 4 \mathrm{H}_{2} \mathrm{O}\right]\end{array}$ \\
\hline 1 & 50.0 & 17.4 & 25.6 & $7.0[16.2]$ \\
\hline 2 & 70.0 & 10.5 & 15.4 & $4.1[9.5]$ \\
\hline 3 & 72.0 & 9.8 & 14.3 & $3.9[9.0]$ \\
\hline 4 & 72.0 & 4.9 & 21.1 & $2.0[4.6]$ \\
\hline 5 & 72.0 & 2.0 & 25.3 & $0.7[1.6]$ \\
\hline 6 & 72.0 & 1.0 & 26.6 & $0.4[0.9]$ \\
\hline 7 & 72.0 & 0.0 & 28.0 & $0.0[0.0)$ \\
\hline 8 & 75.0 & 8.7 & 12.8 & $3.5[8.1]$ \\
\hline 9 & 78.0 & 7.7 & 11.2 & $3.1(7.2]$ \\
\hline 10 & 80.0 & 7.0 & 10.2 & $2.8[6.5]$ \\
\hline 11 & 82.0 & 6.3 & 9.2 & $2.5[5.8]$ \\
\hline 12 & 85.0 & 5.2 & 7.7 & $2.1[4.9]$ \\
\hline
\end{tabular}

的低融点で熱膨張係数が小さく, 誘電率が低いコーディ エライト組成 $\left(2 \mathrm{MgO} \cdot 2 \mathrm{Al}_{2} \mathrm{O}_{3} \cdot 5 \mathrm{SiO}_{2}\right)$ を選定した。 ムライトとコーディエライトの比率を変えた材料を検討 した. 表 2 中の No. 1 3 及び 8 12 がこれらに相当す る. 更に，誘電率を小さくすることを考え，コーディエ ライト組成にシリカを添加した系を検討した.ムライト 量は 72 wt\% とし，表 2 中の No. 4〜 7 に示すように, アルミナ及びマグネシアは，コーディエライト組成の比 率とし, シリカのみ多く添加した。 なお， $\mathrm{MgO}$ は吸湿 性があるため, 炭酸マグネシウム $\left(\mathrm{Mg}_{5}\left(\mathrm{CO}_{3}\right)_{4}(\mathrm{OH})_{2} \cdot 4\right.$ $\left.\mathrm{H}_{2} \mathrm{O}\right)$ の形で添加した。

\section{3 焼結体の作製方法}

\subsection{1 スラリの作製方法}

原料粉末 $200 \mathrm{~g}$ に, 樹脂 (平均重合度 1000 のポリビ ニルブチラール） $12.92 \mathrm{~g}$ 及びアルミナボール（申15 $\mathrm{mm} ; 30$ ケ， $\phi 20 \mathrm{~mm} ; 15$ ケ）を加え，ポリエチレン製 容器 $(500 \mathrm{ml})$ 中で乾式混合した後, 可塑剤 (ブチルフ タリルブチルグリコレート） $4.14 \mathrm{ml}$ 及び溶剤（トリク ロロエチレン $103.0 \mathrm{ml}$, テトラクロロエチレン $51.4 \mathrm{ml}$ 及び $n$-ブチルアルコール $45.6 \mathrm{ml}) 200 \mathrm{ml}$ を中に投入 し, $24 \mathrm{~h}$ 混合した. ボールミル混合によりスラリ中に混 入した気泡を真空かくはん装置中で脱気処理し, グリー ンシート作製用スラリとした.

\subsection{2 グリーンシートの作製方法}

スラリを, ドクターブレード法によりグリーンシート にした7). 装置は, 横山製作所製実験室用グリーンシー 卜作製機である. スラリをシリコーン処理したポリエス テルフィルム上に流し， $0.5 \mathrm{~mm}$ の間隙を通すことによ り, 一定の厚さに塗布した. 塗布したスラリは, ポリエ ステルフィルムとともに $0.3 \mathrm{~m} / \mathrm{min}$ の速度で乾燥装置
内に送り，スラリ中の溶剤を除去し，厚さ $0.23 \mathrm{~mm}$ の グリーンシートを作製した。

\subsection{3 焼結体の作製方法}

実際の基板を作製する場合には，グリーンシートにW ペーストでスルーホール及び導体配線を施し, 窒素, 水 素及び水蒸気雾囲気中で焼成するが，今回の実験では新 しいムライト系材料の開発を主目的としたため, 簡便に 大気中で焼成した。なお, 窒素, 水素及び水蒸気雾囲気 中で焼成した材料の特性は，大気中で焼成したものと同 様であることを確認している.

グリーンシートを $50 \mathrm{~mm} \square$ にパンチ器で切断し，コー タキ社製ホットプレス機を用いて, $120^{\circ} \mathrm{C} \times 5.0 \mathrm{~min}$, 2. $45 \mathrm{MPa}$ の条件で積層し, 24 枚の積層板を作製した. この積層板をシリコニット電気炉にセットした後, 大気 中で $50^{\circ} \mathrm{C} / \mathrm{h}$ の速度で昇温し, $1200^{\circ} \mathrm{C}$ で $1 \mathrm{~h}$ 保持するこ とにより, 積層板中の樹脂分を除去した. その後, カン タルガデリウス社製カンタルスーパー炬を用いて大気中 で焼成した．焼成条件は，基板の作製に適した $1600^{\circ} \mathrm{C}$ $\times 1.0 \mathrm{~h}$ を主体とした.

\section{4 焼結体の評価方法}

\subsection{1 密度}

密度測定用試験片は, 焼結体を幅 $10 \mathrm{~mm}$, 厚さ $4 \mathrm{~mm}$, 長さ $40 \mathrm{~mm}$ にダイヤモンドカッターで切り出して得た. かさ密度の測定には, 長計量器製作所製自動比重測定装 置を用いた，材料組成が異なるため，構成成分の密度を 用いて換算し，相対密度で示した。.なお，今回の実験に 用いたムライト原料は, 化学量論比よりわずかにアルミ ナ過剩な組成であるため, その密度は $3.20 \mathrm{~g} / \mathrm{cm}^{3}$ (化 学量論比のムライト $\left.: 3.14 \mathrm{~g} / \mathrm{cm}^{3}\right)$ である.

\subsection{2 ボイド率}

焼結体の破面の SEM 写真を用い, 浜松テレビ製画像 処理装置によりボイド率を算出した。ボイド率は, 2 視 野の平均値とした。

\subsection{3 比誘電率}

比誘電率測定用試験片は, 焼結体を $30 \mathrm{~mm}^{\square}$ にダイヤ モンドカッターで切断し, 厚さ $1 \mathrm{~mm}$ までダイヤモンド 研磨機で研磨して作製した。比誘電率は，Dupont 社製 $4817 \mathrm{Ag}$ ペーストを用いて，この試験片の両面に $\phi 20$ $\mathrm{mm}$ の電極を形成した試料を用いて測定した。焼結体の 比誘電率 $\varepsilon_{\mathrm{r}}$ は, 次式から求めた。

$$
\varepsilon_{\mathrm{r}}=\frac{C}{\varepsilon_{0}} \cdot \frac{d}{S}
$$

ここで, $C:$ キャパシタンス $(\boldsymbol{F}), \varepsilon_{0}$ : 真空中の誘電 率 $(0.88542 \mathrm{~F} / \mathrm{m}), d$ : 試験片の厚さ $(1 \mathrm{~mm}), S:$ 電 極の面積 $\left(314.16 \mathrm{~mm}^{2}\right)$ である.

試料のキャパシタンスは, Yokogawa Hewlet Packard 製 4192A-LF Impedance Analyzer を用いて測定し た。 


\section{4.4 曲げ強さ}

曲げ強さは，島津製作所製オートグラフ DSS -5000 を用いて 4 点曲げ試験により求めた. 曲げ試験片は, 焼 結体から幅 $4 \mathrm{~mm}$, 厚さ $3 \mathrm{~mm}$, 長さ $36 \mathrm{~mm}$ の棒状に切 り出し,ダイヤモンド研磨機を用いて全面を鏡面研磨し て作製した.曲げ試験は, JIS-R-1601 に準拠して行い ${ }^{8)}$,

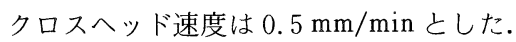

\subsection{5 熱膨張係数}

熱膨張係数測定用試験片は, $\phi 5 \mathrm{~mm}$, 長さ $20 \mathrm{~mm}$ に 切断, 研磨して作製した. 測定には, 理学電機製 8003 $\mathrm{H}$ 型示差熱膨張計を用いた。標準試料には, 石英ガラ ス $\left(\alpha=0.52 \times 10^{-6} /{ }^{\circ} \mathrm{C}\right)$ を用いた。

\section{4.6 微構造}

焼結体の微構造は, 走査型電子顕微鏡 $(\mathrm{SEM})$ 及び 透過型電子顕微鏡 (TEM) を用いて観察した. SEM 観察には, 日立製作所製 S-800 型走査型電子顕微鏡を, TEM 観察には, 日立製作所製 H-700H 型高分解能分析 電子顕微鏡を用いた.

\subsection{7 結晶構造}

結晶構造は, 焼結体をアルミナ製乳鉢で粉砕し, 粉末 X線回折法を用いて解析した。解析に用いた装置は, 理 学電機製ロータフレックス型広角 X線回折装置である. $\mathrm{X}$ 線の照射条件は, ターゲット: $\mathrm{Cu}$, 電圧 : $40 \mathrm{kV}$, 電 流：100 mAである。結晶相は, Powder Diffraction File 及び ASTM (American Society for Testing Material) カードにより同定した.

\section{3. 結果及び考察}

\section{1 ムライトーコーディエライト系材料}

ムライトに焼結助剤としてコーディエライト組成を用 いた系について検討した. ムライト量と相対密度及びボ イド率との関係を図 1 に示す.また, 図 2 には, ムライ 卜量と比誘電率及び曲げ強さとの関係を示す.ここで, 相対密度は, ムライトの密度 $3.20 \mathrm{~g} / \mathrm{cm}^{3}$ とし, コーディ エライトの密度を $2.50 \mathrm{~g} / \mathrm{cm}^{3}$ として計算した値である. ムライトーコーディエライト系材料の相対密度は, ム ライト量 $50 \mathrm{wt} \%$ では $91.3 \%$ と小さい.これは, 焼結 助剤のコーディエライト組成量が多いために $1600^{\circ} \mathrm{C} \times$ $1.0 \mathrm{~h}$ では，過焼結になったものと考えられる.また， ムライト量が 70〜 $82 \mathrm{wt} \%$ の範囲では相対密度約 $96 \%$ でほぼ一定であり，十分に焼結できている。しかし，ム ライト量 $85 \mathrm{wt} \%$ では少し減少する.これは, 焼結助剤 としてのコーディエライト組成量が少なくなり, $1600^{\circ} \mathrm{C}$ では十分焼結していないためである. また, ボ イド率には少しばらつきがあり，ムライト量 $50 \mathrm{wt} \%$ の 試料では相対密度から予想される值より若干大きいが, 相対密度との間には良い相関性が認められた。

比誘電率は，ムライト量が $82 \mathrm{wt} \%$ までは, ムライト

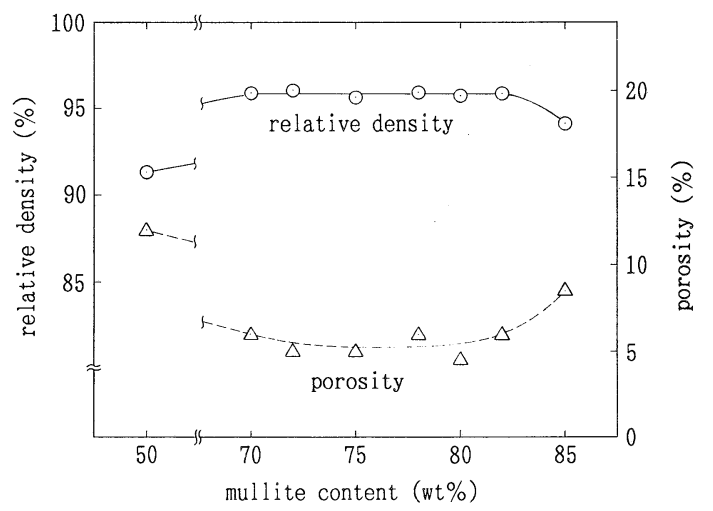

Fig. 1. Dependences of mullite content on relative density and porosity.

glass composition : $\left(\mathrm{Al}_{2} \mathrm{O}_{3}: 35.0, \mathrm{MgO}: 14.0, \mathrm{SiO}_{2}\right.$ : $51.0 \mathrm{wt} \%$ )

sintering conditions : $1600^{\circ} \mathrm{C} \times 1.0 \mathrm{~h}$

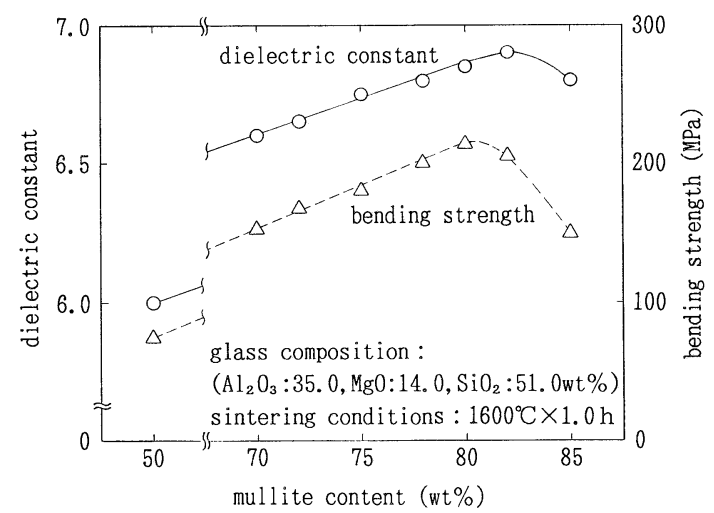

Fig. 2. Dependences of mullite content on dielectric constant and bending strength.

量の増加とともに増加する傾向を示すが, ムライト量が 85 wt \% では少し減少する. ムライト量 $85 \mathrm{wt} \%$ で比誘 電率が減少するのは, 相対密度及びボイド率から分かる ように, 焼結体がポーラスで十分に焼結できていないた めである.

ムライトーコーディエライト系材料では, ムライト量 が $50 \mathrm{wt} \%$ で比誘電率 6.0 が得られたが, ガラス量が多 いため, 焼結による変形が大きく, また, 焼結体がかな りポーラスである.

曲げ強さは，ムライト量が $80 \mathrm{wt} \%$ までは, ムライト 量の増加とともに増加する傾向を示すが, それ以上増加 すると小さくなる. 曲げ強さは，ムライト $80 \mathrm{wt} \%$ で最 大となり, 約 $215 \mathrm{MPa}$ である. 比誘電率が小さいムラ イト量 $50 \mathrm{wt} \%$ の場合は, 曲げ強さが約 $65 \mathrm{MPa}$ と小さ な值を示している。これは, ガラス成分の存在割合が多 いため, 比較的強度の低いガラスに影響され, 曲げ強さ が小さいものと考えられる. 一方, ムライト量が 82 wt \% より多い場合には，ガラス成分が少ないために, 
$1600^{\circ} \mathrm{C}$ の焼成ではいまだ焼結が不十分で，曲げ強さが 小さくなったものと考えられる。

このように，ムライトーコーデイエライト䒺材料では， 曲げ強さが $200 \mathrm{MPa}$ 以上の材料組成を見いだすことが できたが，その試料では比誘電率が大きい，一方逆に， 比誘電率が 6.0 の材料では, 曲げ強さが小さい問題があ り，この系では基板材料として十分なものは得られな 加た。

\section{2 ムライトーガラス系材料}

比誘電率を小さくするために, シリカの比誘電率が約 4 と小さいことに着目し，焼結助剤としてコーディエラ イト組成にシリカを添加した材料を検討した。コーディ エライト組成にシリカを添加することによりガラスの融 点が高くなり，材料の焼結温度が高くなることが考えら れる、ムライト量を $50 \mathrm{wt} \%$ から $85 \mathrm{wt} \%$ まで変えて， 焼結助剂（ガラス）中のシリカ量の検討を行った結果,

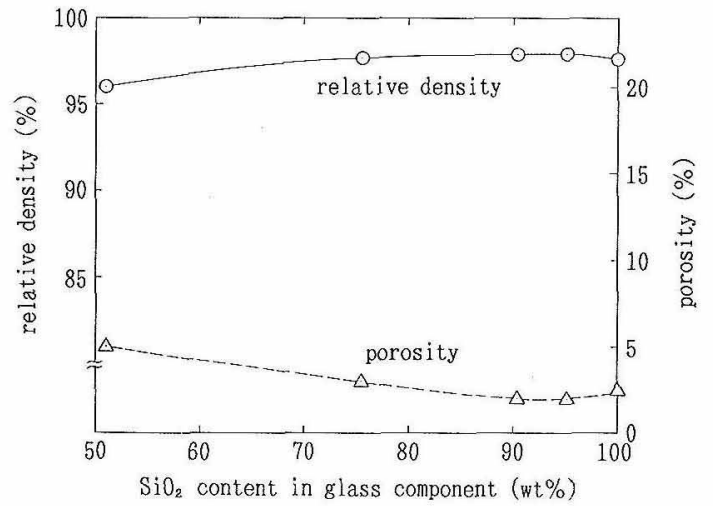

Fig. 3. Dependences of silica content on relative density and porosity. mullite content : $72.0 \mathrm{wt} \%$ sintering conditions: $1600^{\circ} \mathrm{C} \times 1.0 \mathrm{~h}$
ムライト量が $78 \mathrm{wt} \%$ より多い材料は， $1600^{\circ} \mathrm{C} \times 1.0 \mathrm{~h}$ で焼結が不十分となり，また，ムライト量が50 wt％の 場合には，ガラス量が多いために焼結時に型くずれを生 じた. $1600^{\circ} \mathrm{C} \times 1.0 \mathrm{~h}$ の焼結条件の下では，ムライト量 $70 \sim 75 \mathrm{wt} \%$ で良好な焼結体が得られた。ここでは，一 例としてムライト量 $72 \mathrm{wt} \%$ について示す.

\subsection{1 相対密度及びボイド率}

焼結助剂として添加したガラス(コーディエライト組 成+シリカ) 中の $\mathrm{SiO}_{2}$ 量と相対密度及びボイド率との 関係を図 3 に示す.ここで, 相対密度は, ムライト, コー デイエライト及びシリカの密度をそれぞれ 3.20，2.50 及び $2.22 \mathrm{~g} / \mathrm{cm}^{3}$ として計算した值である.シリカは原 料混合時には石英で添加しているが，焼結体中では非晶 質になっているため，石英ガラスのデータを用いた。

相対密度は, ガラス中の $\mathrm{SiO}_{2}$ 量を增すとともに若干 大きくなる，また，ボイド率は，ガラス中の $\mathrm{SiO}_{2}$ 量を 増すと少なくなる傾向がある、このように, 焼結助剤と してコーディエライト組成にシリカを添加すると, 焼結 体が緻密になることが分かった。がラス中の $\mathrm{SiO}_{2}$ 量が 約 $90 \mathrm{wt} \%$ 以上で, 相対密度約 $98 \%$, ボイド率約 $2 \%$ の材料が得られた。

ガラス中の $\mathrm{SiO}_{2}$ 量を変えて作製した焼結体の破断面 の SEM 写真を図 4 に示す.ガラス中の $\mathrm{SiO}_{2}$ 量を多く するとボイドが小さく，また，少なくなっている．同時 に，ムライト粒子はガラス中の $\mathrm{SiO}_{2}$ 量が多いと小さく なっているため，シリカにムライトの粒成長を抑制する 効果があると考えられる.

\section{2 .2 焼結体の特性}

図 5 には, ガラス中の $\mathrm{SiO}_{2}$ 量と熱膨張係数, 比誘電 率及び曲げ強さとの関係を示す.

熱膨張係数は，ガラス中の $\mathrm{SiO}_{2}$ 量を多くすると小さ

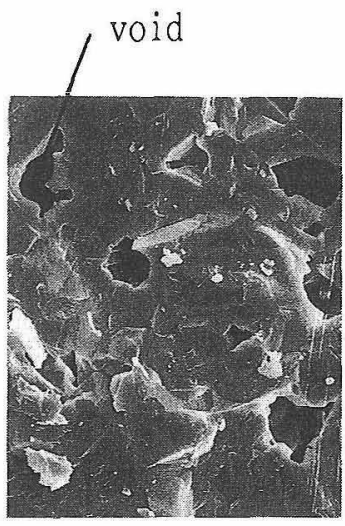

51.0

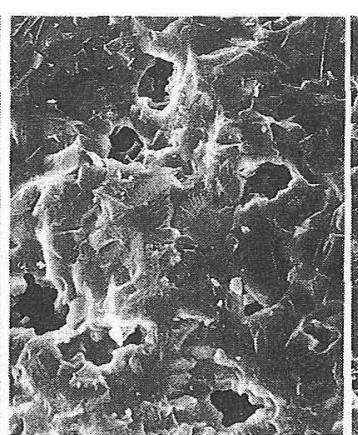

75.5

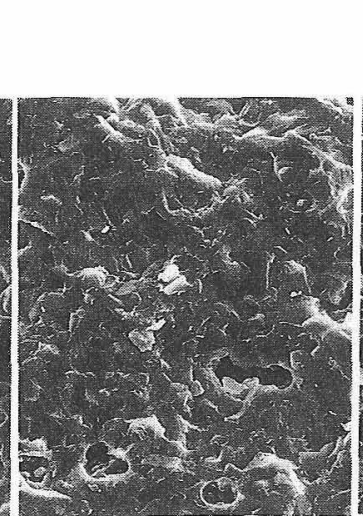

90.2

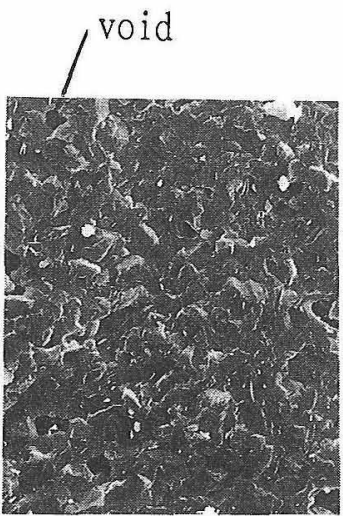

95.1

\section{$\mathrm{SiO}_{2}$ content in glass component (wt\%)}

$30 \mu \mathrm{m}$

Fig. 4. SEM photographs of fracture surface. mullite content : $72.0 \mathrm{wt} \%$, sintering conditions : $1600^{\circ} \mathrm{C} \times 1.0 \mathrm{~h}$ 


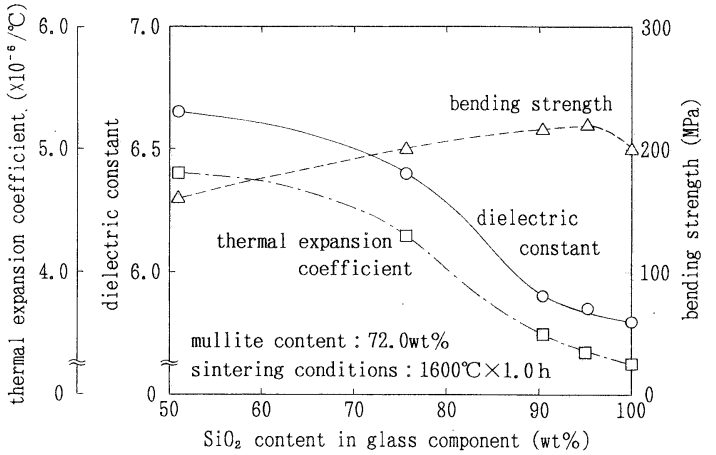

Fig. 5. Effects of $\mathrm{SiO}_{2}$ content on thermal expansion coefficient, dielectric constant and bending strength.

くなる傾向がある.これは, 焼結助剤として添加したコー デイエライト組成及びシリカが非晶質になり, 熱膨張係 数が小さい $\mathrm{SiO}_{2}$ リッチのガラスを形成したためと考え られる. ガラス中の $\mathrm{SiO}_{2}$ 量が約 $90 \mathrm{wt} \%$ 以上で, 熱膨 張係数約 $3.5 \times 10^{-6} /{ }^{\circ} \mathrm{C}$ 以下の材料を得ることができた. これらの材料は, シリコンの熱膨張係数 $\left(3.5 \times 10^{-6} /{ }^{\circ} \mathrm{C}\right)$ とほぼ同じであり，シリコン素子を搭載する基板として 有効である。

比誘電率は, 熱膨張係数と同様にガラス中の $\mathrm{SiO}_{2}$ 量 を多くすると小さくなる傾向がある.これは，シリカの 比誘電率が小さいためである. ガラス中の $\mathrm{SiO}_{2}$ 量が約 $90 \mathrm{wt} \%$ 以上で, 比誘電率を 5.9 以下にすることができ た. 従来のアルミナ基板（9.5）に比べてかなり小さく, 電気信号伝播の高速化に有効である. 電気信号の伝播遅 延時間は, 比誘電率の平方根に反比例するため, この材 料ではアルミナに比べて約 2 割小さくなることが予想で きる。

曲げ強さは，ガラス中の $\mathrm{SiO}_{2}$ 量を多くすると大きく なる傾向がある。これは，焼結助剤としてコーディエラ イト組成にシリカを添加することにより，相対密度が大 きく，また，ムライトの粒径が小さくなることの影響と 考えられる. しかし, $\mathrm{SiO}_{2}$ 量が $100 \mathrm{wt} \%$ のガラスでは, わずかに減少している．この原因としては，焼結助剤と して添加したシリカの融点が高いために，図 3 に見られ るように若干焼結不十分になった可能性が高い。これら の結果，ガラス中の $\mathrm{SiO}_{2}$ 量が 75 100 wt\% の領域にお いて，曲げ強さ $200 \mathrm{MPa}$ 以上を達成することができた。

以上の結果は，ムライト量が $70 \mathrm{wt} \%$ 及び $75 \mathrm{wt} \%$ に おいてもほぼ同様であった。また，この材料組成におい ては，焼結温度 $1560^{\circ} \sim 1660^{\circ} \mathrm{C}$ の範囲で十分緻密な焼結 体を得ることができた。

以上，基板材料として良好な特性を持つ，ムライト量 が 70〜 75 wt \% ，ガラス中の $\mathrm{SiO}_{2}$ 量が 90〜 100 wt \% の 組成のムライトーガラス系材料を開発した.

\section{3 微構造}

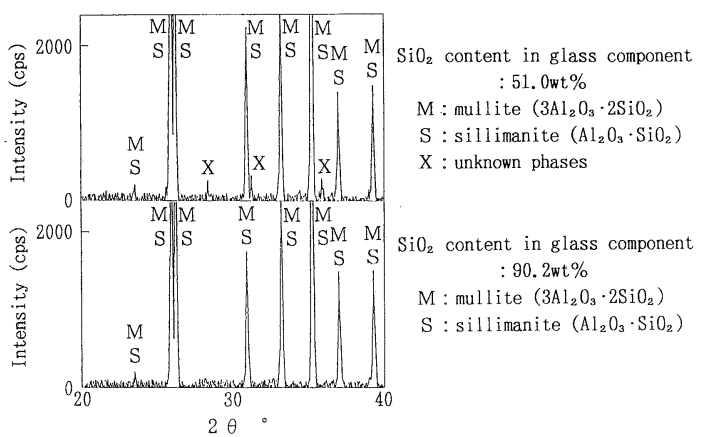

Fig.6. X-ray diffraction patterns of mullite ceramics. mullite content : $72.0 \mathrm{wt} \%$ sintering conditions : $1600^{\circ} \mathrm{C} \times 1.0 \mathrm{~h}$

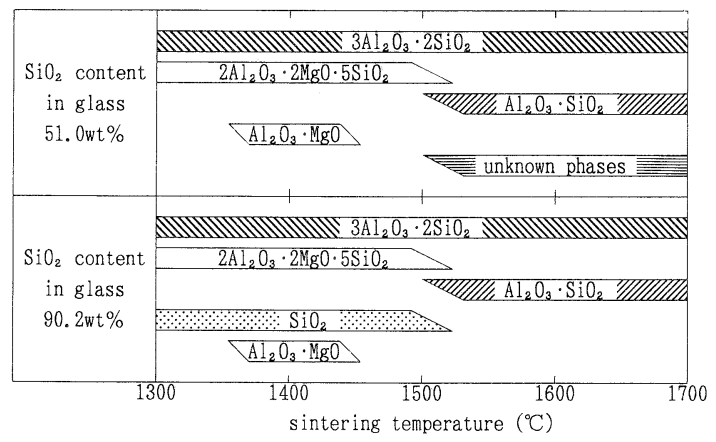

Fig. 7. Crystalline phase change in mullite ceramics at various sintering temperature. mullite content : $72.0 \mathrm{wt} \%$

\subsubsection{X線回折}

ムライト-ガラス系材料の X 線回折図形の代表例を図 6 に示す.ムライト量は $72 \mathrm{wt} \%$ とし，ガラス中の $\mathrm{SiO}_{2}$ 量による焼結体中の結晶相の違いについて検討し た. ガラス中の $\mathrm{SiO}_{2}$ 量としては，51.0 wt\% 及び 90.2 $\mathrm{wt} \%$ の 2 種類について比較を行った. ガラス中の $\mathrm{SiO}_{2}$ 量が 51.0 wt \% の場合には，ムライトとシリマナイト以 外に不明な相（図中X）が生成している。これは，焼結 助剤として添加したアルミナ，シリカ及びマグネシアか らなる結晶相と考えられるが，その同定が困難であった。 一方, ガラス中の $\mathrm{SiO}_{2}$ 量が 90.2 wt \% の場合には，結 晶相として存在するものはムライトとシリマナイトのみ である。なお，X線回折による解析では，結晶構造が近 似しているムライトとシリマナイトの区別が困難であ る. そこで, 電子線回折による手法により結晶相の同定 を行った。詳細は, 次項 (TEM 観察) で説明する.

次に，焼結温度による結晶相の変化を図 7 に示す。ガ ラス中の $\mathrm{SiO}_{2}$ 量が $51.0 \mathrm{wt} \%$ の場合には, 焼結助剤と して添加したアルミナ，シリカ及びマグネシアがコー ディエライトを形成し， $1400^{\circ} \mathrm{C}$ 付近でスピネルをわず かに生成する.また, $1500^{\circ} \mathrm{C}$ 以上の温度においては, コ一 デイエライトが消失し，シリマナイトとアルミナ，シリ 

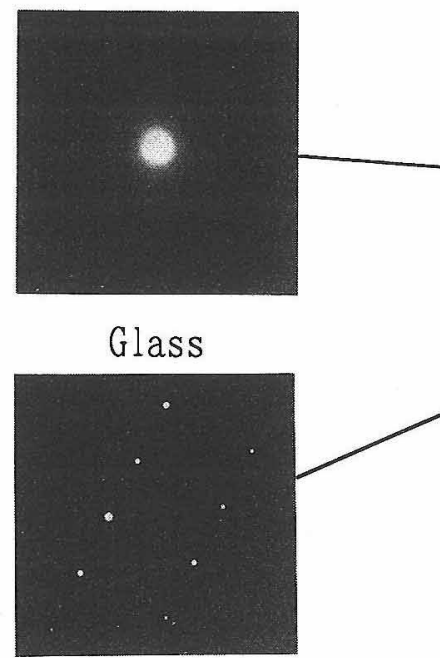

(211)

$(000)$

Mullite $\left(3 \mathrm{Al}_{2} \mathrm{O}_{3} \cdot 2 \mathrm{SiO}_{2}\right)$

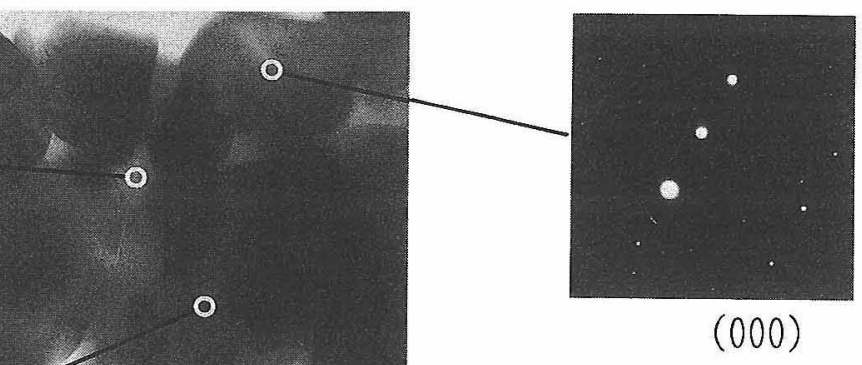

$(200)$

Sillimanite

$2 \mu \mathrm{m}$

\section{$\left(\mathrm{Al}_{2} \mathrm{O}_{3} \cdot \mathrm{SiO}_{2}\right)$}

$3 \mathrm{Al}_{2} \mathrm{O}_{3} \cdot 2 \mathrm{SiO}_{2}+\mathrm{SiO}_{2} \rightarrow 3\left(\mathrm{Al}_{2} \mathrm{O}_{3} \cdot \mathrm{SiO}_{2}\right)$

$\mathrm{Al}_{2} \mathrm{O}_{3}+\mathrm{SiO}_{2} \rightarrow \mathrm{Al}_{2} \mathrm{O}_{3} \cdot \mathrm{SiO}_{2}$

$\left(\mathrm{Al}_{2} \mathrm{O}_{3}\right.$ in $\mathrm{Al}_{2} \mathrm{O}_{3} \cdot \mathrm{MgO}$ and $\left.2 \mathrm{Al}_{2} \mathrm{O}_{3} \cdot 2 \mathrm{MgO} \cdot 5 \mathrm{SiO}_{2}\right)$

Fig. 8. TEM photograph and electron diffraction patterns of mullite ceramics. mullite content: $72.0 \mathrm{wt} \%$ glass composition : $\left(\mathrm{Al}_{2} \mathrm{O}_{3}: 7.0, \mathrm{MgO}: 2.8, \mathrm{SiO}_{2}: 90.2 \mathrm{wt} \%\right)$

カ及びマグネシアからなる不明な結晶相が生成する。こ の不明な結晶相は，焼成温度が変わるとピーク位置が変 わり, 安定していない。一方，ガラス中の $\mathrm{SiO}_{2}$ 量が $90.2 \mathrm{wt} \%$ の場合には, $1500^{\circ} \mathrm{C}$ 以下の温度でコーディエ ライト以外に過剩に添加したシリカが存在する。また, $1400^{\circ} \mathrm{C}$ 付近では，ガラス中の $\mathrm{SiO}_{2}$ 量が $51.0 \mathrm{wt} \%$ の場 合と同様に，スピネルがわずかに生成する。 $1500^{\circ} \mathrm{C}$ 以 上の温度においては，コーディエライト及びシリカが消 失し, 結晶相としてムライトとシリマナイトのみとなる。 焼結助剂としてシリカリッチの組成とすることで, 結晶 相の安定化が図れている。

\subsubsection{TEM 観察}

ムライトーガラス系材料の TEM 写真及び電子線回折 パターンを図 8 に示す.ムライト量は $72 \mathrm{wt} \%$ ，ガラス 中の $\mathrm{SiO}_{2}$ 量は $90.2 \mathrm{wt} \%$ である. TEM 写真中の粒子 の大きさは，2－6 $\mu \mathrm{m}$ 程度であり，出発原料として用い たムライト粒子からあまり粒成長していない。これは，

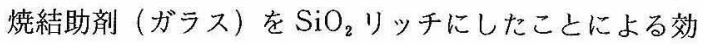
果と考えられる。

電子線回折による解析を行った結果, 粒子はムライト とシリマナイトの 2 種類の結晶相からなっていることが 分かった。 また, 粒子間には, 非晶質のがラスが介在し ている.このガラスは, 定性分析の結果, $\mathrm{SiO}_{2}$ リッチ の相であった．また，焼結助剤として添加したマグネシ
アはムムライトとシリマナイト結晶粒子及びガラス中に 拡散固溶し，結晶としては存在していない。

シリマナイトの生成には，次の二通りの場合が考えら れる. (1)ムライトと焼結助剤として添加したシリカが反 応して生成した。(2)焼結助剂中のアルミナとシリカから 生成した。(1)の場合には，ムライト原料の一部がガラス に溶け込み，シリカと反応してシリマナイトを生成する ことと, ムライト粒子にシリカが拡散固溶し, 結晶構造 を変えることが考えられる. (2)の場合には, 前項 (X線 回折）で示したように，昇温過程で焼結助剤がコーディ エライト及びスピネル結晶に変化し，これが消失する際 にシリマナイトを生成するものと考えられる、シリマナ イトは，上記いずれの場合でも生成する可能性がある.

\section{4. 総 括}

基板材料に要求される特性を満足するムライト系材料 を得るため，焼結助剤であるガラスの組成について検討 した. 得られた焼結体の密度, 誘電率, 曲げ強さ及び熱 膨張係数について評価し, 次の結果を得た。

(1) ムライト量が 70〜 75 wt\%，ガラス中の $\mathrm{SiO}_{2}$ 量が 90 -100 wt\% の組成範囲で，比誘電率 6 以下，曲 げ強さ $200 \mathrm{MPa}$ 以上及び熱膨張係数約 $3.5 \times 10^{-6} /{ }^{\circ} \mathrm{C}$ の ムライトーガラス系材料を得た。これらの材料の結晶相 は，安定なムライト及びシリマナイトのみからなる。 
（2）ムライトに添加するガラス中の $\mathrm{SiO}_{2}$ 量を増加 すると, 比誘電率及び熱膨張係数が小さく, 曲げ強さが 大きくなる傾向がある.

（3） $\mathrm{SiO}_{2}$ を添加すると曲げ強さが大きくなるのは, ムライト粒子の粒成長が抑制され，ボイドが少なくなる ためである。

\section{文献}

1) I. A. Aksay and J.A. Pask, J. Am. Ceram. Soc., 58, 507-12 (1975).

2) N. Kamehara, K. Niwa and K. Murakawa, IMC 1982
Proceedings, Tokyo, 388-93.

3) G.S. Perry, Trans. Brit. Ceram. Bull., 72, 279-83 (1973).

4) S. Kanzaki, T. Kukihara, S. Iwai, M. Ohashi and H. Tabata, Yogyo-Kyokai-Shi, 95, 1213-18 (1987).

5) M. L. Keith and J.F. Schairer, J. Geol., 60, 182 (1952).

6) W. D. Kingery, H. K. Bowen and D. R. Uhlmann, "Introductino to Ceramics, Second ed.", John Wiley \& Sons, Inc. (1976) pp.307-11.

7）齊藤勝義, “ファインセラミックスの成形と有機材料”, (株)シーエムシー (1985) pp. 219-53.

8）日本規格協会, “JIS ハンドブック セラミックス” (1984) pp. 169-70. 